\title{
Karakteristik Penderita Tumor Mediastinum di RSUP Dr. M. Djamil Padang Periode 2015-2019
}

\author{
Nur Izzah Atirah ${ }^{1}$, Aisyah Ellyanti', Zelly Dia Rofinda ${ }^{3}$ \\ ${ }^{1}$ Fakultas Kedokteran Universitas Andalas, Padang \\ ${ }^{2}$ Bagian Radiologi dan Kedokteran Nuklir Fakultas Kedokteran Universitas Andalas/RSUP Dr. M. Djamil Padang \\ ${ }^{3}$ Bagian Patologi Klinik Fakultas Kedokteran Universitas Andalas/RSUP Dr. M. Djamil Padang
}

\begin{abstract}
A B S T R A C T
Latar Belakang. Tumor mediastinum merupakan salah satu kelainan di rongga mediastinum dengan berbagai spektrum klinis dan jenis histopatologi. Di Indonesia masih sedikit penelitian dan literatur mengenai tumor mediastinum. Khususnya di Padang, masih kekurangan karakteristik epidemiologi, klinis, dan karakteristik histopatologi dari tumor mediastinum.
\end{abstract}

Objektif. Penelitian ini bertujuan untuk mengetahui karakteristik dari tumor mediastinum di RSUP Dr. M. Djamil Padang.

Metode. Penelitian ini merupakan penelitian deskriptif observasional dengan desain cross sectional. Data penelitian didapatkan dari rekam medis yang memenuhi kriteria sampel periode 2015 - 2019. Kriteria inklusi dari penelitian ini adalah seluruh rekam medis pasien dengan diagnosis klinis tumor mediastinum, dan kriteria eksklusinya adalah tidak lengkap umur dan jenis kelamin pasien, status merokok, lokasi tumor, gambaran klinis, serta jenis histopatologi tumor. Hasil penelitian dikelompokkan dalam tabel distribusi frekuensi.

Hasil. Penelitian didapatkan 40 sampel yang memenuhi kriteria inklusi. Pasien tumor mediastinum kebanyakan berusia 51-60 tahun $(27,5 \%)$, berjenis kelamin laki-laki (55\%), dan hampir separuh pasien memiliki riwayat merokok (47,5\%). Lokasi massa terbanyak pada kompartemen anterior. Pasien umumnya datang dengan keluhan sesak napas $(82,5 \%)$, diikuti oleh batuk, nyeri dada, dan penurunan berat badan. Jenis tumor mediastinum yang paling sering terjadi adalah tumor timus $(42,5 \%)$. Kematian saat perawatan di rumah sakit mencapai 7,5\%.

Kesimpulan. Tumor mediastinum lebih banyak terjadi pada pasien di atas umur 51 tahun, berjenis kelamin laki-laki, dengan tumor timus sebagai jenis histopatologi yang paling umum.

Kata Kunci: karakteristik, tumor mediastinum, mediastinum.

Background. Mediastinal tumors are considered to be mediastinal disease with various clinical and histopathologic presentations. In Indonesia, literatures concerning mediastinal tumors are still few. Especially in Padang, we are still lacking of epidemiology, clinical, and histopathology characteristics of mediastinal tumors.

Objective. This study aims to obtain the characteristic of mediastinal tumors patients in Dr. M. Djamil Hospital.
Method. A cross-sectional observational descriptive study was conducted using medical records from 2015 to 2019. All medical records with clinical diagnosis of mediastinal tumors are included, and cases without the presence of age, gender, history of smoking, location of tumors, clinical symptoms and histopathologic findings are excluded. Data were collected and presented in table.

Result. There were 40 cases total samples collected. Patients with mediastinal tumors were mainly 51-60 years old (27.5\%), especially were mostly of males (55\%), and almost half of them had history of smoking (47.5\%). The most frequent mass location was in the anterior compartement. Patients mainly had chief complaints of dyspnea (82.5\%), followed by cough, chest pain, and weight loss. The most common type of mediastinal tumor is thymic (42.5\%). Mortality during hospitalization reached $7.5 \%$.

Conclusion. This study concludes that mediastinal tumor mainly occurs in males aged 51 years old and above, with thymic tumors as the most common histopathologic findings. Keywords: characteristics, mediastinal tumor, mediastinum.

Apa yang sudah diketahui tentang topik ini?

Tumor mediastinum mempunyai berbagai karakteristik.

Apa yang ditambahkan pada studi ini?

Kematian penderita tumor mediastinum saat perawatan di rumah sakit.

\section{CORRESPONDING AUTHOR}

\section{Name: Nur Izzah Atirah}

Phone: 082285243745

E-mail: atthardinur@gmail.com

\section{ARTICLE INFORMATION}

Received: September $23^{r d}, 2020$

Revised: October $15^{\text {th }}, 2020$

Available online: Oktober $31^{\text {st }}$, 2020 


\section{Pendahuluan}

Tumor mediastinum adalah suatu massa abnormal di ruang antara paru kanan dan kiri. Tumor ini merupakan tumor yang jarang dibanding tumor jenis lainnya dan kebanyakan tumor mediastinum tumbuh lambat.1,2 Penegakan diagnosis untuk tumor mediastinum adalah satu tugas yang sulit bagi dokter dan ahli patologi dikarenakan banyak massa yang berupa jinak dan ganas dapat ditemukan di rongga mediastinum, selain letak tumor yang bertumpang tindih dengan organ lain dan struktur vaskuler yang kompleks. ${ }^{3}$

Mediastinum adalah suatu rongga yang berada di antara paru kanan dan kiri dan mempunyai banyak sturktur anatomi vital didalamnya. Rongga mediastinum sempit dan tidak dapat diperluas, sehingga apabila terjadi pembesaran tumor dapat menekan organ disekitarnya dan menimbulkan kegawatan yang mengancam jiwa.2,3 Angka kejadian tumor mediastinum berkisar 24\%-47\% pada orang dewasa dan pada anak-anak adalah 35\%-50\%.4 Penelitian yang dilakukan pada 9000 pasien yang dicurigai tumor paru dilakukan CT Scan Toraks didapatkan $0,77 \%$ merupakan massa di mediastinum. ${ }^{5}$

Tumor mediastinum ditemukan pada semua kelompok umur. Frekuensi tertinggi yang berisiko adalah pada dekade ke-3 hingga dekade ke-5.4 Rentang usia pasien tumor mediastinum terdapat pada berbagai usia tergantung dengan jenis tumor mediastinum. ${ }^{6}$ Berdasarkan jenis kelamin, tumor mediastinum diketahui dapat ditemukan, baik pada pria maupun wanita. ${ }^{1}$ Jenis kelamin bukan merupakan predileksi terhadap tumor mediastinum, namun berdasarkan jenis sel tumor ditemukan perbedaan yang bermakna. ${ }^{7}$ Data dari Framinghan Heart Study didapatkan peningkatan dua kali lipat prevalensi tumor mediastinum anterior pada perokok $(0,4 \%)$ dari penelitian sebelumnya. 8

Tumor mediastinum sering tidak menimbulkan gejala dan terdeteksi saat pasien dilakukan foto toraks, namun pasien biasanya datang ke fasilitas kesehatan apabila telah terdapat keluhan. ${ }^{2,9}$ Penderita tumor mediastinum datang ke layanan kesehatan dengan gejala klinis yang bervariasi dan seringnya memiliki lebih dari satu gejala tergantung lokasi tumor dan organ yang terlibat.2,6 Lokasi terbanyak ditemukan massa adalah pada mediastinum anterior.10 Beberapa tumor mediastinum melibatkan 2 hingga 3 lokasi ruang mediastinum. ${ }^{6}$

Limfoma, timoma, dan teratoma adalah jenis tumor mediastinum yang paling sering ditemukan. Dari kepustakaan luar negeri, diketahui bahwa jenis yang banyak ditemukan pada tumor mediastinum anterior adalah limfoma, timoma, dan tumor sel germinal. ${ }^{2}$ Massa mediastinum dapat ditemukan secara insidentil pada beberapa kasus, seperti saat dilakukan pemeriksaan kesehatan rutin. Lesi mediastinum sulit dideteksi pada rontgen toraks karena lesi ini merupakan jaringan lunak dan dikelilingi oleh jaringan lunak pula. CT-Scan sangat penting untuk mengetahui keberadaan massa, sedangkan pemeriksaan histopatologi digunakan untuk mengarahkan terapi. ${ }^{11,12}$

Saat ini penelitian mengenai tumor mediastinum di Indonesia, khususnya Kota Padang masih jarang dilakukan, sehingga penelitian ini diharapkan dapat memperluas wawasan mengenai karakteristik tumor mediastinum dan mampu membantu klinisi dalam memperkirakan diagnosis pasien sehingga memungkinkan tatalaksana dengan optimal.

\section{Metode}

Penelitian dimulai dari pembuatan proposal kemudian dilanjutkan dengan pengambilan data dari buku registrasi bangsal paru dan instalasi rekam medis RSUP Dr. M. Djamil Padang pada bulan Maret 2020 hingga April 2020. Penelitian bersifat deskriptif observasional dengan desain cross sectional. Variabel yang diteliti adalah umur, jenis kelamin, status merokok, lokasi tumor, gejala klinis, dan karakteristik histopatologi dari tumor. Sampel penelitian berjumlah 40 orang. Sampel didapatkan dengan metode total sampling. Instrumen yang digunakan adalah buku registrasi bangsal Paru dan rekam medik pasien. Data hasil penelitian dicatat dan dicari persentase kemudian ditampilkan dalam bentuk tabel distribusi frekuensi.

Penelitian ini telah lulus kaji etik oleh Komite Etik Penelitian Kesehatan RSUP Dr. M. Djamil Padang dengan nomor surat bernomor 153/KEPK/2020. 


\section{Hasil}

Hasil penelitian ini terdata 95 pasien yang didiagnosis tumor mediastinum, namun hanya 40 $(42,1 \%)$ pasien yang memenuhi kriteria inklusi dan eksklusi. Hal ini disebabkan tidak semua pasien tumor mediastinum memiliki data yang lengkap untuk setiap variable yang diteliti.

Tabel 1. Frekuensi Umur Penderita Tumor Mediastinum

\begin{tabular}{lcc}
\hline \multicolumn{1}{c}{ Umur (tahun) } & $\mathbf{n}$ & $\mathbf{\%}$ \\
\hline$\leq 20$ & 2 & 5,0 \\
$21-30$ & 10 & 25,0 \\
$31-40$ & 7 & 17,5 \\
$41-50$ & 7 & 17,5 \\
$51-60$ & 11 & 27,5 \\
$61-70$ & 1 & 2,5 \\
$\geq 71$ & 2 & 5,0 \\
\hline
\end{tabular}

Berdasarkan Tabel 1 dapat dilihat bahwa penderita tumor mediastinum paling banyak terdapat pada rentang umur 51-60 tahun sebanyak 11 orang $(27,5 \%)$ dengan rata-rata usia penderita yang didapatkan adalah 41,8 tahun, yaitu pasien termuda berumur 18 tahun dan pasien tertua 85 tahun.

Tabel 2. Frekuensi Penderita Tumor Mediastinum Berdasarkan Jenis Kelamin dan Status Merokok

\begin{tabular}{lcc}
\hline Karakteristik & n & \% \\
\hline Jenis Kelamin & & \\
Laki-laki & 22 & 55 \\
$\quad$ Perempuan & 18 & 45 \\
Status Merokok & & \\
$\quad$ Perokok & 15 & 37,5 \\
Bekas perokok & 4 & 10,0 \\
Bukan perokok & 21 & 52,5 \\
\hline
\end{tabular}

Tabel 2 memperlihatkan karakteristik pasien dengan tumor mediastinum, ditinjau dari jenis kelamin. Dari seluruh data yang didapatkan, lebih setengah pasien pada penelitian ini adalah lakilaki 22 (55\%) dan sisanya perempuan 18 (45\%) orang. Pada tabel 2 ini, dapat terlihat status merokok penderita tumor mediastinum, dimana dari 40 pasien telah dipastikan bahwa 19 sampel memiliki riwayat merokok yang terdiri dari perokok aktif $(37,5 \%)$ dan bekas perokok $(10 \%)$. Separuh lagi dari sampel penelitian ini adalah bukan perokok $(52,5 \%)$.

Tabel 3. Frekuensi Penderita Tumor Mediastinum Berdasarkan Lokasi Tumor

\begin{tabular}{lcc}
\hline \multicolumn{1}{c}{ Lokasi Tumor } & $\mathbf{n}$ & $\mathbf{\%}$ \\
\hline Anterior & 39 & 97,5 \\
Medial & 0 & 0 \\
Posterior & 1 & 2,5 \\
\hline
\end{tabular}

Hasil ini dapat dilihat pada tabel 3, dimana sebagian besar kasus tumor mediastinum terjadi di rongga anterior yaitu sebanyak 39 kasus (97,5\%). Sisa 1 kasus merupakan tumor mediastinum posterior. Tidak terdeteksi tumor mediastinum medial di RSUP Dr. M. Djamil periode 2015- 2019.

Tabel 4. Frekuensi Penderita Tumor Mediastinum Berdasarkan Gejala Klinis

\begin{tabular}{lcc}
\hline \multicolumn{1}{c}{ Gejala Klinis } & n & \% \\
\hline Gejala respirasi & & \\
Batuk & 31 & 77,5 \\
Sesak napas & 33 & 82,5 \\
Nyeri dada & 22 & 55,0 \\
Gejala nonrespirasi & & \\
Penurunan berat badan & 17 & 42,5 \\
Demam & 8 & 20,0 \\
Pembengkakan anggota tubuh & 4 & 10,0 \\
Limfadenopati & 7 & 17,5 \\
Suara serak & 8 & 20,0 \\
Keringat malam & 2 & 5,0 \\
Sulit menelan & 3 & 7,5 \\
\hline
\end{tabular}

Gejala klinis dapat dibagi dalam dua kelompok, yaitu gejala respirasi dan gejala nonrespirasi (tabel 4). Gejala klinis pada penderita tumor mediastinum dengan frekuensi paling tinggi ditemukan adalah dari gejala respirasi, yaitu sesak napas sebesar $82,5 \%$, kemudian diikuti oleh batuk $77,5 \%$ dan nyeri dada 55\%. Gejala nonrespirasi yang paling banyak dikeluhkan adalah penurunan berat badan $42,5 \%$, selanjutnya diikuti dengan demam dan suara serak masing-masing sebanyak $20 \%$, limfadenopati $17,5 \%$, pembengkakan anggota tubuh $10 \%$, dan paling sedikit sulit menelan 7,5\% dan keringat malam 5\%.

Tabel 5. Frekuensi Penderita Tumor Mediastinum Berdasarkan Karakteristik Histopatologi

\begin{tabular}{lcc}
\hline $\begin{array}{c}\text { Karakteristik } \\
\text { Histopatologi }\end{array}$ & n & \% \\
\hline Limfoma & 10 & 25,0 \\
Tumor timus & 17 & 42,5 \\
Tumor sel germinal & 10 & 25,0 \\
Tumor neurogenik & 1 & 2,5 \\
Lain-lain & 2 & 5,0 \\
\hline
\end{tabular}

Diagnosis tumor mediastinum berdasarkan karakteristik histopatologi dapat dilihat pada tabel 5. Kasus terbanyak yang didapatkan adalah tumor timus seramai $17(42,5 \%)$ orang, diikuti limfoma 10 (25\%) orang, tumor sel germinal 10 (25\%) orang, tumor neurogenik $1(2,5 \%)$ orang, 
dan tumor mediastinum lain terdapat 2 (5\%) orang. Berdasarkan seluruh data yang didapatkan, 3 (7,5\%) penderita dari 40 sampel tumor mediastinum meninggal selama pengobatan di rumah sakit.

\section{Pembahasan}

Hasil penelitian menunjukkan 40 pasien yang didiagnosis tumor mediastinum yang memenuhi kriteria sampel. Terdapat 55 data rekam medis terpaksa dieksklusi karena tidak mencantumkan data tentang karakteristik histopatologi dari tumor mediastinum. Banyak faktor yang menyebabkan hal tersebut diantaranya, seperti kesulitan dokter untuk melakukan tindakan diagnostik, belum sempatnya dilakukan pemerikasaan lanjutan karena keadaan umum pasien yang jelek, serta pasien yang menolak tindakan diagnostik. Angka ini tidak dapat dilakukan perbandingan karena belum ada penelitian sebelumnya di Kota Padang.

Kelompok umur terbanyak terdapat pada umur 51-60 tahun dengan jumlah 11 (27,5\%) orang. Hasil ini berbeda jika dibandingkan dengan penelitian Dixit et al yang mendapatkan kelompok usia dengan angka kejadian tertinggi adalah 21-30 tahun dan penelitian Pratama et al, 41-50 tahun.3,6 Dari hasil penelitian didapatkan bahwa rerata umur 41,8 tahun dengan pasien termuda berusia 18 tahun dan pasien tertua berusia 85 tahun. Hasil ini sesuai dengan penelitian di India yang dilakukan oleh Aroor et al. yang mendapatkan rentang umur pasien tumor mediastinum mulai dari 17 tahun hingga 68 tahun dengan umur rerata 45,4 tahun. ${ }^{13}$ Hasil ini sesuai teori bahwa rentang umur penderita tumor mediastinum terdapat pada berbagai kelompok usia. ${ }^{6}$

Hasil penelitian ini didapatkan bahwa tumor mediastinum lebih banyak ditemukan pada pasien laki-laki dibanding perempuan. Hal ini sesuai dengan hampir semua penelitian sebelumnya. Hasil penelitian dari Giovoni et al di Bandung mendapatkan $73,6 \%$ berjenis kelamin laki-laki. ${ }^{1}$ Peneliti lain mengatakan jenis kelamin bukan merupakan predileksi tumor mediastinum, hasil ini seperti yang didapatkan oleh Rabbani et al. yang tidak mendapatkan perbandingan yang ketara dengan hasil 58 laki-laki dan 52 perempuan. ${ }^{14}$ Hal itu sejalan dengan hasil penelitian ini yang tidak mendapatkan kemaknaan pada perbandingan antara laki-laki dan perempuan serta tiada kaitan pengaruh hormon dengan tumor mediastinum.

Penelitian ini mendapatkan $47,5 \%$ penderita tumor mediastinum mempunyai riwayat merokok. Pada penelitian Dixit et al. didapatkan 27,3\% adalah perokok aktif. ${ }^{3}$ Hasil daripada penelitian ini mendapatkan kasus tumor mediastinum lebih banyak terjadi pada bukan perokok. Hal ini mendukung teori bahwa tidak ada pengaruh yang signifikan antara faktor risiko riwayat merokok dengan tumor mediastinum. ${ }^{8}$

Hasil penelitian ini sesuai teori bahwa tumor mediastinum anterior merupakan tumor terbanyak dari seluruh tumor mediastinum. ${ }^{2}$ Berdasarkan pemeriksaan imaging yang dilakukan pada penderita dalam penelitian ini ditemukan tumor di rongga anterior sebanyak 39 kasus $(97,5 \%)$. Hal serupa juga didapatkan pada penelitian Rabbani et al. dan juga Dutta et al., bahwa rongga anterior merupakan lokasi tersering terjadinya tumor mediastinum yaitu masing-masing sebanyak 101 kasus $(91,8 \%)$ dan 25 kasus (50\%). ${ }^{10,14}$

Gejala klinis tumor mediastinum dapat ditemukan pada seluruh penderita $(100 \%)$ tumor mediastinum dalam penelitian ini dan tiada pasien yang datang tanpa gejala. Gejala respirasi paling sering ditemukan sebagai keluhan utama. Sesak dan batuk pada penderita tumor mediastinum dapat disebabkan oleh hambatan pengembangan paru akibat desakan massa, maupun penekanan pada trakea. Sedangkan nyeri dada dirasakan akibat adanya penekanan pada sistem saraf dinding dada. Gejala lokal lain yang ditemukan seperti suara serak dan sulit menelan dapat diakibatkan dari penekanan massa tumor di nervus laringius dan esofagus. ${ }^{2}$ Hasil penelitian ini sejalan dengan penelitian di India yang menemukan semua gejala lokal pada penderita tumor mediastinum yaitu batuk $(91,3 \%)$, sesak napas $(83,4 \%)$, nyeri dada $(60,4 \%)$, sulit menelan $(13,6 \%)$, dan suara serak $(10,7 \%){ }^{3}$

Gejala nonrespirasi pula kebanyakan merupakan gejala sistemik yang terkait dengan pelepasan hormon, antibodi, dan sitokin. ${ }^{15}$ Penurunan berat badan merupakan gejala nonrespirasi yang paling banyak $(42,5 \%)$ ditemukan pada penelitian ini, berbeda dengan Pandey et al (2018) yang mendapatkan hanya 1 dari 60 pasien yang datang keluhan ini. ${ }^{12}$ Gejala klinis, seperti penurunan berat badan, demam, 
limfadenopati, dan keringat malam yang ditemukan dalam penelitian ini merupakan gejala sistemik yang dapat dihubungkan dengan proses keganasan sel tumor, seperti yang dinyatakan dalam penelitian Amin. ${ }^{15}$

Hasil penelitian ini didapatkan bahwa tumor timus merupakan jenis tumor yang paling sering terjadi, yaitu sebanyak 17 kasus $(42,5 \%)$, terdiri dari 15 kasus timoma, 1 kasus karsinoma timik, dan 1 tumor karsinoid, diikuti limfoma sebanyak 25\%. Penelitian yang dilakukan oleh Giovani et al. juga mendapatkan hasil bahwa karakteristik histopatologi pada pasien tumor mediastinum yang terbanyak adalah tumor timus yang mencapai $68,4 \%$ kasus. ${ }^{1}$ Beberapa penelitian yang menunjukkan hasil serupa, antara lain penelitian oleh Singh et al. (2013), yaitu ditemukan timoma sebanyak 31,5\%, dan oleh Dutta et al. (2014) sebanyak $18 \% .9,10$ Beberapa hasil penelitian lain menyatakan bahwa limfoma mediastinal memiliki frekuensi yang lebih tinggi, seperti penelitian oleh Dixit et al. (2017), sebanyak 19,4\%, Rabbani et al (2016), sebanyak 49,5\%, dan Asgary et al. (2016), sebanyak $43,6 \%{ }^{3,4,14}$

Tumor mediastinum jenis sel germinal pada penelitian ini sebanyak 10 orang (25\%), yaitu terdiri dari 9 kasus jenis teratoma dan 1 kasus tumor yolk sac. Hasil ini berbeda dengan literatur yang dinyatakan oleh Pratama dalam penelitiannya bahwa prevalensi tumor mediastinum jenis sel germinal 1-3\% dari seluruh pasien tumor mediastinum. ${ }^{6}$ Pada penelitian ini juga ditemukan 2 kasus tumor endokrin jenis tiroid dan 1 kasus tumor mediastinum neurogenik jenis neurofibroma.

Berdasarkan hasil penelitian ini didapatkan angka kematian dalam masa pengobatan di rumah sakit sebanyak $7,5 \%$ dari 40 penderita yang didiagnosis tumor mediastinum dari tahun 2015 hingga 2019. Angka kematian selama pengobatan yang didapatkan oleh Singh et al (2013) lebih tinggi, yaitu sebanyak 39,8\% dengan 52,9\% daripadanya belum diketahui karakteristik histopatologi sel tumor. Hasil uji statistik dari penelitian itu mendapat faktor yang paling mempengaruhi mortalitas tumor mediastinum adalah sepsis. ${ }^{9}$ Hal ini dibuktikan oleh Aroor et al (2014) dimana kedua-dua kasus kematian tumor mediastinum di Rumah Sakit Kasturba, India adalah disebabkan sepsis. ${ }^{13}$
Kelemahan dalam penelitian ini adalah masih banyaknya kejadian tumor mediastinum yang belum diketahui karakteristik histopatologi sel, sehingga hasil penelitian ini kemungkinan belum menggambarkan kejadian tumor mediastinum yang sebenarnya, serta dalam penelitian ini hanya terbatas pada pasien yang dirawat di RSUP Dr. M. Djamil saja.

\section{Simpulan}

Tumor mediastinum lebih banyak terjadi pada pasien di atas umur 51 tahun, terutama pada jenis kelamin laki-laki dibanding perempuan. Gejala yang paling umum dari klinis tumor mediastinum adalah sesak napas, diikuti oleh batuk, nyeri dada, dan penurunan berat badan. Frekuensi tertinggi jenis histopatologi dari tumor mediastinum adalah tumor timus.

\section{Ucapan Terima Kasih}

Penulis mengucapkan terima kasih kepada pembimbing, kepala dan seluruh staff RSUP Dr. M. Djamil Padang, serta semua yang telah membantu penulis dalam menyelesaikan penelitian ini.

\section{Daftar Pustaka}

1. Giovoni O, Agustina $\mathrm{H}$, Djajakusumah TM. Karakteristik Tumor Mediastinum di RSUP Dr. Hasan Sadikin Bandung. Journal of Medicine and Health. 2018; 2(2): 773-9.

2. Perhimpunan Dokter Paru Indonesia. Tumor Mediastinum: Pedoman Diagnosis dan Penatalaksaan di Indonesia. Edisi ke 1. Jakarta: Badan Penerbit FKUI. 2003;2-13.

3. Dixit R, Shah NS, Goyal M, Patil CB, Panjabi M, Gupta $\mathrm{RC}$, et al. Diagnostic evaluation of mediastinal lesions. Lung India. 2017; 34(4): 341-8.

4. Asgary MA, Aghajanzadeh M, Hemmati H, Jafari M. Epidemiology of Mediastinal Tumors during Six Year (2006-2012) In Rasht City. Acta Medica Mediterranea. 2016; 32: 1244-47.

5. Broaddus VC, Mason RJ, Ernst JD, Jr TEK, Lazarus SC, Murray JF et al (2016). Murray \& Nadel's Textbook of Respiratory Medicine. Elsevier, p: 1478-95.

6. Pratama S, Syahruddin E, Hudoyo A. Karakteristik tumor mediastinum berdasarkan keadaan klinis, gambaran CT scan dan petanda tumor di rumah sakit Persahabatan. Jakarta: FKUI. 2008: 4-21.

7. Syahruddin E, Hudoyo A, Jusuf A. Penatalaksanaan tumor mediastinum ganas. Departemen Pulmonologi dan Ilmu Kedokteran Respirasi. FKUI- RS Persahabatan, Jakarta. 2007: 2-12.

8. Araki T, Nishino M, Gao W, Dupuis J, Washko GR, Hunninghake GM et al. Anterior Mediastinal Masses in the Framingham Heart Study. European Journal of Radiologi Open. 2015; 2: 26-31

9. Singh G, Amin Z, Wuryantoro, Wulani V, Shatri H. Profile of Mediastinal Mass patients and Factors Associated with Mortality During Hospitalization in 
Cipto Mangunkusumo Hospital. Acta Med Indonesiana. 2013; 45: 3-10.

10. Dutta P, Patel KKR, Choudhury PR. Mediastinal Masses: A Radiological Study of 50 Cases. IJBR. 2014; 5(7): 468-73.

11. Sakka D, Smadhi H, Tkhayat AB, Kamoun H, Akrout I, Greb D, et al. Mediastinal masses: Clinical, radiological and pathological analysis. European Respiratory Journal. 2018; 52(62): 1.

12. Pandey S, Jaipal U, Mannan N, Yadav R. Diagnostic accuracy of multidetector computed tomography scan in mediastinal masses assuming histopathological findings as gold standard. Pol J Radiol. 2018; 83: e234.

13. Aroor AK, Prakasha RS, Seshadri S, Teerthanath S, Raghurah U. A study of clinical characteristics of mediastinum mass. Journal of clinical and diagnostic research. 2014; 8(2): 77-80

14. Rabbani M, Sarrami AH. Computed tomography-guided percutaneous core needle biopsy for diagnosis of mediastinal mass lesions. Departemen radiologi Rumah Sakit Alzahra, Iran. 2016: 3

15. Amin Z. Demographic, Clinic, Radiologic, and Histopathologic Pattern of Patient with Mediastinal Mass who Died during Treatment at Cipto Mangunkusumo Hospital Jakarta. Indonesian Journal of Cancer. (2013a); 7(1): 7-13. 